\title{
Joseph Ratzinger's Argument for the Epistemological Seriousness of Faith
}

\author{
KRZYSZTOF KAUCHA
}

The John Paul II Catholic University of Lublin

krzysztof.kaucha@kul.pl, ORCID: 0000-0003-3884-763X

\begin{abstract}
Christianity, and the Christian faith, seems to be losing when confronted with scientific reason and scientific certainty. Christianity needs new arguments for the epistemological seriousness of its faith. Those could be found in Joseph Ratzinger's writings, providing new insights into fundamental theology. The subject of faith as an element that is crucial to him (and to Christianity) pervades all his works. This paper aims at proving that Ratzinger has worked out an original epistemological way of defending the Christian faith. It is an attempt to recreate his argument on the basis of his entire intellectual output. The present research leads to the conclusion that Ratzinger's way of argumentation is quite unique. In classical fundamental theology, the Christian faith (comprehended mostly as an individual act of faith) is placed at its end point, while in Ratzinger's fundamental theology, faith (understood mostly as a historical and communal act) is practically a point of departure. From the beginning of his reasoning Ratzinger (due to his meta-faith perspective) persuades that the Christian faith is epistemologically very serious. Faith may not only manifest its presence alongside other serious attitudes to reality, but also be capable of demonstrating its foundation, rationality, originality, uniqueness, and even absoluteness (definitiveness).
\end{abstract}

Keywords: Joseph Ratzinger, Christianity, faith, fundamental theology, argument, argumentation

Joseph Ratzinger (b. 1927, now Pope emeritus Benedict XVI) has called upon the Church to reinstitute the "argument about the rationality of belief or unbelief" and develop "the new presence of the rationality of faith" because she seems to be losing when confronted with scientific reason:

That is one task the Church has today: to revive the argument about the rationality of belief or unbelief. Belief is not an opponent of reason, but the advocate of its true stature, as the Pope [John Paul II] has depicted with passionate commitment in his encyclical Faith and Reason. The struggle for the new presence of the rationality of faith is what I regard as an urgent task for the Church in our century. Faith should not withdraw into its own shell, behind a decision for which it gives no further reason; it should not shrink into being no

The article is part of the 028/RID/2018/19 project of "Regional Initiative of Excellence" in 2019-2022, funded by Poland's Ministry of Education and Science (11,742,500 PLN). 
more than a kind of system of symbols, in which people can make themselves at home but which would ultimately remain a random choice among other visions of life and the world. It needs the wide realm of open reason; it needs the confession of faith in the Creator God, for without this confession of faith even Christology is diminished; it then talks only indirectly about God, by referring to a particular religious experience, while this, however, is necessarily limited and would then become just one experience among others. ${ }^{1}$

There is no doubt that this is truly an urgent task for the Church, especially for (in the academic world) fundamental theology ${ }^{2}$ (among Protestant Christians sometimes known as apologetics). My intention here is to prove on the basis of Ratzinger's entire intellectual output (currently available only in German ${ }^{3}$ and Polish ${ }^{4}$ ) that he not only challenges the Church and fundamental theology to act, but also as a theologian he has found a distinct way of defending the Christian faith epistemologically: upholding its epistemological rationality, uniqueness, and dignity (epistemological seriousness). I am going to recreate Ratzinger's argumentation in a condensed manner by collecting its main premises preceded by a general description of his understanding of the Christian faith.

Ratzinger's line of reasoning differs from the traditional, classic method of argumentation - typically employed by Catholic (but not only) theologians and philosophers - called the fides et ratio argument. Obviously, this term alludes to John Paul II's encyclical letter bearing the same title. Generally speaking, the fides et ratio argument is to demonstrate the unity, connection, harmony, symbiosis and interdependence between the Christian faith and reason, and their necessary mutual complementation. It draws on the centuries-old intellectual tradition of Christianity that has produced astonishing amalgams of faith and reason in the form of medieval systems. The beginnings of this tradition go back to antiquity and the Church $\mathrm{Fa}-$ thers. It gave rise to two complementary principles: credo ut intellegam and intellego ut credam. ${ }^{5}$ The belief that faith and reason are in consonance and that there is no contradiction between them was distinctly expressed in the documents created by the First Vatican Council. ${ }^{6}$

This conviction also stands out in Ratzinger's entire output, containing numerous references to the relationship between the Christian faith (fides) and reason (ratio). ${ }^{7}$

1 Ratzinger, "The Church on the Threshold," 284-298. As a rule, the quotations were taken from Ratzinger's texts published in English, otherwise, they come from the Polish edition translated into English by Tomasz Pałkowski.

2 Rusecki - Mastej - Kaucha, Metodologia.

3 Published in Gesammelte Schriften collection (1-16; 2009-2019).

4 Published in Joseph Ratzinger Opera Omnia collection (1-16, 2012-2020).

5 John Paul II, Fides et ratio, 16-35.

6 Borto, Magisterium, 95-178.

7 Kałuża, "Josepha Ratzingera koncepcja," 63-77; Lekka-Kowalik, "Przymierze na rzecz rozumu," 17-31; Fisichella, "Verità." 
His words speak with great force: "Faith would not be true to itself if it shunned reason. Its proper tasks include combating ignorance and eliminating false piety. The desire for education springs from within."

It seems, though, that this is not the core (and the final) point of Ratzinger's thinking. For him non-contradiction and harmony between the Christian faith and reason are not ultimate conclusions. It simply could not be so. Ratzinger recognizes that it is impossible to uphold the belief that nowadays the Christian faith and reason are in simple consonance when scientific reason produces a new notion of reality and truth. This reason rejects God and religious faith from the realm of rationality (as irrational, subjective, and epistemologically weak). The Bavarian theologian does not stop at the fides et ratio argument but goes much further. He profoundly explores the Christian faith from inside and is certain that this faith can defend itself epistemologically "from itself."

\section{Understanding the Christian Faith}

According to Ratzinger, Christianity is essentially about believing. The structure of the Christian faith contains both an internal (fides qua creditur) and external component (fides quae creditur). ${ }^{9}$ It is true that the Christian faith exists "inside" man, who simply believes inside his own self. Personal faith starts with a decision to say "yes" to faith, to be converted, to make a "leap" into faith. This is why Ratzinger calls faith "a fundamental decision which affects all spheres of our existence and which exists only when it is sustained by all powers of our existence," "an all-encompassing movement of human existence," "an about-turn by the whole person," "a shift of being" or, to use the biblical language, an act of the heart (Rom 10:9)..$^{10}$ The latter not only consists in choosing God, choosing Jesus as the Truth, but is also in entrusting oneself to him and to one's love for him. ${ }^{11}$ If this conclusive turn, this entrusting of oneself, is authentic and done wholeheartedly, it becomes - along with the Christian existence thus begun - an inner validation of faith. Faith then becomes the source of certainty. However, Ratzinger emphasizes (and this is essential for fundamental theology) that, even then, the very subject and his/her power of decision do not ultimately make faith a certain truth (epistemologically serious), but that God, who invites us to believe (who speaks and acts, and patiently builds his history with people), does: "Faith is possible only because it was God who first turned to me, because it was Christ

\footnotetext{
Ratzinger, Wiara w Piśmie, II, 815-816.

Mastej, Od objawienia; Mastej, "Wiara," 1323-1324.

Ratzinger, Introduction, 47-48.

Ratzinger, Introduction, 44.
} 
who leans over me, speaking to me and inviting me to follow Him. Faith is possible because from the very beginning the Creator instils in me an inner dynamic so that my being inwardly strives after God. Now, what must happen is that this encounter really takes place." ${ }^{2}$

Thanks to the decision to believe, people of faith will see with greater clarity and certainty that they are not alone, that they are sustained in their existence by God, Jesus, and the Truth. By virtue of the decision to believe, people embed themselves in the enduring Truth and - using the language of St. Augustine and Ratzinger - they become true. It is now that they discover that, thanks to the Christian faith, the truth exists, that it is reality, and that it forever comes along with Jesus, Logos Incarnate.

The Christian faith is seen by Ratzinger as a unique phenomenon. In other religions or epistemologically serious approaches to life we can only find some remote analogies:

The kernel of Christianity shall be that it is a 'belief'. We generally assume rather unthinkingly that 'religion' and 'belief' are always the same thing and that every religion can therefore just as well be described as a 'belief'. But this is true only to a limited extent; many of the other religions have other names for themselves and thus establish different centers of gravity. The Old Testament as a whole classified itself, not as 'belief', but as 'law'. It is primarily a way of life, in which, to be sure, the act of belief acquires by degrees more and more importance. Again, by religio Roman religious feeling understood in practice mainly the observance of certain ritual forms and customs. ${ }^{13}$

For Ratzinger, the Christian faith is a specific spiritual stance, which "generically" is completely different from reason and knowledge, "acting" completely independently of them:

Let us repeat the same thing once again in another form: Belief in the sense intended by the Creed is not an incomplete kind of knowledge, an opinion that subsequently can or should be converted into practical knowledge. It is much rather an essentially different kind of intellectual attitude, which stands alongside practical knowledge as something independent and particular and cannot be traced back to it or deduced from it. Belief is ordered, not to the realm of what can be or has been made, although it is concerned with both, but to the realm of basic decisions that man cannot avoid making, in one form. ${ }^{14}$

The Christian faith is available to everyone. It does not depend on knowledge, education, or social status. The Christian faith is the immediacy of the bond with

\footnotetext{
12 Ratzinger, Wiara w Piśmie, I, 94.

13 Ratzinger, Introduction, 28.

14 Ratzinger, Introduction, 39-40.
} 
God because Jesus Christ himself is the immediacy. This is the core of this faith from the beginning: "In Christ the mediator we meet God directly and it is here that Christ shows Himself as a real mediator who leads to immediacy; even more than that: He is the immediacy." ${ }^{15}$ Belief enables a genuinely immediate relationship, being together, understanding each other, being bound to each other, a real community between man and the living and true God. This faith is a way of overcoming the obvious and unbreakable (for Plato and Platonism, and many others today) distance between man and God.

This is precisely why belief lies at the core of Christianity. For Ratzinger, belief is simple: Christians just believe in God. They believe not in something, not in anything higher or more powerful than man, but in God, and only in God. The declaration of the Christian belief is very brief: "I believe in You" and "I believe in Jesus Christ." It states that Christians have met the living God and that, in meeting Jesus, they encounter the "presence of the Eternal One in this world" and the "You" - the purpose of the world. ${ }^{16}$

Moreover, Ratzinger tells us what Christian belief is not. It is neither a purely intellectual act nor exclusively a volitional or an emotional act. ${ }^{17}$ It is an action engaging the whole human person: all his or her existence and being. Although an individual's faith starts with his or her autonomous decision, it neither follows from this decision nor "hinges" on it. If this were so, its foundation would be very weak. An individual decision to believe hinges on the invitation to believe that comes from "outside": from God Himself, as well as from the real community of faith (the Church) and the history of the people of that faith. Faith is not an unthinking acceptance of the doctrinal and moral system of belief or a combination of traditions, or repeated practices that could give man something valuable. Faith initiated by a personal opening to Jesus as Christ is a way of life. Faith is not only a so-called act of faith - a oneoff moment when the decision to embrace faith is taken or renewed - but a path for all of one's life, the art of living, and life's most important criterion.

The Christian faith is a belief in a God who has revealed Himself and Who is revealed in the world in a real way; as such, belief is manifested in specific content, formulations, truths of faith. In Ratzinger's opinion, belief can not only manifest itself in certain kinds of content, but it also wants to do so (as it has done from the beginning), and believes that only in this way can it stay true to itself and be taken seriously. The Christian faith does not speak with ambiguous symbols and metaphors (as Far Eastern religions do), but through lucid substance which it finds real and true. ${ }^{18}$

15 Ratzinger, Głosiciele Słowa, 107. In the original German version: "Im Mittler Christus begegnen wir Gott unmittelbar, und eben darin erweist er sich als der wahre Mittler, dass er zur Unmittelbarkeit führt oder vielmehr: sie selber ist" (Ratzinger, Künder des Wortes, 113).

16 Ratzinger, Wiara w Piśmie, II, 882; Ratzinger, Introduction, 43-44.

17 Ratzinger, Wiara $w$ Piśmie, II, 881.

18 Ratzinger, Principles, 328. 
This substance contains elements that are both accessible and inaccessible to human cognition. They are united into one, or "wedded" to each other. ${ }^{19}$ They are united by faith, and this combination ("being wedded") is one of its irreplaceable functions.

For Ratzinger, it is obvious that the essence of the Christian faith can be expressed by every truly-believing Christian - who has his or her own unique life and history of faith - in their own way, with their own words and experiences. If, based on Ratzinger's whole output, we analyse faith and extract its structure, we could point out its core assumptions. However, we need to bear in mind that what Ratzinger believes to be crucial is the fact that the Christian faith relies on simplicity, unity, and immediacy. Only faith (as a simple act of a whole person: whole "I") inherently unites and integrates the numerous elements of its structure and dimensions. This occurs primarily thanks to the immediacy of "access" to God, the immediacy of communion with him, which belief presupposes, and thanks to which faith is at all possible. For truly believing Christians Jesus Christ is the Truth because he (and only he) is the immediacy of God. Without this closeness, it would be impossible to experience the Christian faith, talk about it, or advance any arguments based on it.

\section{Premises of the Argument for the Epistemological Seriousness of Faith}

A general explanation of Ratzinger's understanding of the Christian faith serves as introduction to recreating his argumentation (in a form of condensed premises) for the epistemological seriousness of faith.

\subsection{The First Premise: Limitations of Reason}

We can start by repeating the basic question asked by Ratzinger: Is there really the socalled autonomous, critical, scientific, "pure" reason? And, consequently: Is there "pure" rationality? Ratzinger has serious doubts about this. He believes that such a "sterile" or "ideal" reason does not exist because reason is always - like man himself - entangled in "a myriad of contexts," including those which are barely rational or non-rational. Reason is subject to limitation in many ways. Man is not the Absolute; he is subject to a number of conditions, dependencies, and boundaries, especially nowadays, since, in Ratzinger's opinion, "so much manipulation of our souls occurs"; we are surrounded by "all the talk of this world" and the "murky waters of our information and ideologies." Therefore, appearances and pretence oppress people's

Ratzinger, Kościół, I, 199. 
being and reason. Man is not free, and neither is his reason: "pure reason simply does not exist; its working always depends on a myriad of contexts." ${ }^{20}$ Our cognition has always been limited and incomplete.

There is and will always be a gulf between reality, being, existence, the truth of being, and human language, the latter being the basic tool of reason. Language is not capable of expressing the very reality with words, signs, symbols or myths. It can "imitate" it, but it will merely be a copy, a reflection. And - very importantly the Bavarian theologian thinks that language is necessary and indispensable, because no knowledge whatsoever occurs without it. ${ }^{21}$

For Ratzinger, man (and his reason) is trapped in his selfishness, multiple fears, weaknesses, unresolved guilt, and evil. This is why the experience of truth and reality is marred by error, illusion, fragmentary truth, pride and utopias, all of which constitute the underpinnings of his ideologies. ${ }^{22}$ Man always has to be critical of himself, and approach truth and reality with humility. Reason should also be like this. If reason is humble, it becomes truly critical - it becomes what it is. If it shows no humility, it is not critical and is not what it is. It does not lead to the truth. ${ }^{23}$ Reason alone could not be trusted epistemologically. Reason needs to be epistemologically helped.

\subsection{The Second Premise: Faith Comes (and Must Come) from Outside}

The general structure of faith, Ratzinger argues, has two sides: the external (non-subjective) one, and the internal (subjective) one. The subject's decision to embrace faith is made possible only because the rudiments of faith and a personal invitation to believe come from beyond the subject:

It is important that the faith not only reflects my experience but also that it reaches me from without, that it exists beyond me, that its existence is prior to mine, and that it directs me into this reality... However, man cannot limit himself to inner experience only, which is ultimately subjective; there is also the real. God's action is real: He comes to me as reality from the outside and at the same time from the inside because He embraces me from within and without. ${ }^{24}$

From outside comes God and his Word, Divine Revelation, the message about the existence, divinity, and the concreteness of God, about his love which embraces man, and the whole truth of man's life. This is what radically sets the Christian faith

\footnotetext{
20 Ratzinger, Głosiciele Słowa, 325.

21 Ratzinger, Rozumienie objawienia, 332.

22 Ratzinger, Jesus of Nazareth. Holy Week, 108.

23 Ratzinger, Dogma, 35-36.

24 Ratzinger, $W$ rozmowie, 1189.
} 
apart from philosophy, for which the beginning is not the Word, but thought (and reason) ${ }^{25}$ Although Ratzinger claims that the realness of Divine Revelation is necessarily conditional upon man and his belief in it - without which there is practically no Revelation ${ }^{26}$ - this implies that, without a Word coming from outside, faith would not be possible whatsoever. Faith, then, springs from a gift received from outside from God:

For to believe as a Christian means in fact entrusting oneself to the meaning that upholds me and the world; taking it as the firm ground on which I can stand fearlessly. Using rather more traditional language, we could say that to believe as a Christian means understanding our existence as a response to the word, the logos, that upholds and maintains all things. It means affirming that the meaning we do not make but can only receive is already granted to us, so that we have only to take it and entrust ourselves to it. ${ }^{27}$

This gift is concrete and definitive: Jesus Christ. Ratzinger writes that Divine Revelation consists of giving humanity the reality of Christ. ${ }^{28}$ In essence, the Christian faith "wanted to be none other than understanding: understanding who and what in fact Jesus was. ${ }^{29}$ Ratzinger thinks that the Christian faith started with the Cross event, with an understanding of the paradox that God can be hurt and killed, that God's love in Jesus Christ knowingly reached out to all human misery. ${ }^{30}$ The Christian faith is not an acceptance of a system filled with content, but of the Person, the Person of Jesus Christ. ${ }^{31}$ Ratzinger says that the uniquely precious thing about the Christian faith is that believers "enter through faith into Jesus' unique new origin, and they receive this origin as their own." ${ }^{2}$ Thanks to faith, a believer becomes a new man. This becoming includes, necessarily, a moral dimension. What matters is "a certain style of being human which we do not develop on our own"; rather, it is a gift from Jesus (from outside), who is a fully realised Man. ${ }^{33}$

25 Ratzinger, Introduction, 49, 85.

26 This claim seems to be controversial. Ratzinger has good reasons to justify that claim, but there are also some good reasons supporting the opposite. This controversy among theologians deserves more attention and could not be presented in this article. Whatever solution this controversy finally might have, it does not destroy the second premise.

27 Ratzinger, Introduction, 40-41.

28 Ratzinger, "The Nature of Tradition."

29 Ratzinger, Introduction, 105.

30 Ratzinger, Introduction, 106.

31 Ratzinger, Introduction, 106.

32 Ratzinger, "The question about Jesus' origin." Cf. Mastej, "Paschalna," 145-149.

33 Ratzinger, Wiara $w$ Piśmie, II, 885. 


\subsection{The Third Premise: Only Faith Discloses the Truth of Our Being}

For Ratzinger, there exists a direct connection between the Christian faith and truth. The most telling passage on this issue reads as follows:

Faith regards the truth, by which I mean a kind of knowledge which does not concern the functioning of this or that particular thing, but the truth of our being itself. Thus, faith concerns what we must do to attain the rectitude of our being. These assertions also presuppose that this truth becomes accessible only in the act of faith and that faith is the gift of a new beginning for thought which it is not in our power either to set in existence or to replace. At the very same time, however, they take it for granted that, once accepted, this truth illuminates our whole being and, therefore, also appeals to our intellect and even solicits our understanding. It is assumed that this truth addresses itself as such to reason and requires the activity of reason in order to become man's own possession and to deploy its full dynamism. ${ }^{34}$

The truth of being and the true substance of all things is God - the personal and loving Creator. The purpose of the world and the whole truth about it is contained in the Logos, the Divine Word, in Jesus Christ. ${ }^{35}$ Ratzinger believes the Christian faith implies opening up to the truth about Jesus as the most important and definitive Word and Act of "God pervading us," ${ }^{36}$ which leads us to trust him completely and share in his being. When man makes a decision to open up to Jesus, then Jesus will carry him through life, and man becomes more receptive to the truth. ${ }^{37}$ Jesus then becomes the Way and the Truth and the Life; man becomes a true man. In this way, the truth also becomes reality, in the sense that the subject becomes harmonised with the "object," the whole reality, its truth and meaning. This harmonisation has long been the object of philosophical thinking, in which, however, such a possibility has often been doubted. To Ratzinger, it is extremely important that Christianity is neither a tradition nor a habit, but rather a permanent co-existence with the truth - a life in the truth. He thinks that if Christianity is "practiced" as a tradition or a habit to the exclusion of the dimension of the truth, it is practically non-existent:

If we really do not believe that Jesus Christ is the Son of the living God, the Logos of God, that what He says is true, then Christianity is only a tradition. In such a case Christianity may be beautiful, aesthetic, or attractive in some other way, but it lacks its vital strength. For I am not ready to suffer for a religion that is not true. But Christianity, for which suffering cannot be offered, is ultimately devoid of value because my comfort seems to outweigh

\footnotetext{
Ratzinger, "Conversion, Faith and Thought."

Ratzinger, “On Hope," 308.

Ratzinger, Jezus $z$ Nazaretu, 825.

Ratzinger, Wiara w Piśmie, II, 813; Ratzinger, "Eucharist."
} 
a belief in God. The danger of rejecting the claim to the truth, either allegedly out of respect for others or on account of apparent humility, means in fact that we opt for love of comfort, that we do not accept the greatness of Christianity, that we falsify the faith. ${ }^{38}$

\subsection{The Fourth Premise: No One Has Any Definite Proof, Which Is Why Every Human Person Is Bound to Have Some Kind of Belief}

Ratzinger claims that everyone has to make "crucial decisions" - come to believe and keep faith in something, choose one of the foundations of their lives as the truth in a situation where not only proof of truthfulness or evidence is unavailable, but the gaining of such proof is impossible. ${ }^{39}$ Ratzinger says that the axiom of materialism, idealism, nihilism, relativism, or any other attitude is accepted on trust without any obvious proof, based on stronger or weaker premises, but mainly through intuition. Bearing Ratzinger's thinking in mind, we can ask whether people who claim to have proof or incontrovertible evidence while making "fundamental decisions" are being completely honest? Do they really have any proof? Is this, indeed, proof? According to Ratzinger, scientists prove only that what their tools and methods permit them to; they find answers to their own questions that they have asked earlier; they do not step beyond the empirical (nature) and accept as an axiom that they must not go beyond this realm (naturalism). For Ratzinger, this is an example of the "belief in science." 40 It was surely preceded by a (faith-like) "leap" into the empirical, measurable, mathematical, and naturalistic. It follows from Ratzinger's considerations that there are, strictly speaking, no total non-believers. In the colloquial language of today, the term "non-believer" denotes someone who does not share one's faith in the religious sense, but certainly believes in something or someone (even absolutely at times). Everyone must believe in something or someone.

According to Ratzinger, Christianity says clearly and honestly that there is no proof:

In this sense faith cannot be rationally demonstrated. I cannot say, Whoever does not accept this is just stupid. Faith has its own way of life, in which what we believe is gradually substantiated by experience and is shown to be meaningful as a whole. There are therefore convergences, from the point of view of reason, that make it right for me to enter into it. They give me the certainty that I am not merely handing myself over to some superstition. But an exhaustive demonstration, such as can be given for natural laws, does not exist. ${ }^{41}$

\footnotetext{
38 Ratzinger, Wiara w Piśmie, I, 404.

39 Ratzinger, Introduction, 40.

40 Ratzinger, Jezus z Nazaretu, 907.

41 Ratzinger, "God and Reason."
} 
If there were proof or evidence, faith would be needless, but this is not the case. Faith is necessary and represents a value in itself. Without it, there would be no gifts of faith - and, primarily, man's real freedom. Thus, we need to pose the following question in line with Ratzinger's thinking: If there were proof, and faith was not essential for making "fundamental decisions," would man be truly free in the basic sense of the word? Would he be able to make a fundamental choice about himself in order to determine and direct himself? For Ratzinger, faith always goes hand in hand with freedom and safeguards it.

\subsection{The Fifth Premise: Only Faith Really Gives Freedom}

This premise is related to freedom and refers to man's inherent desire for freedom. It states that man is always painfully affected by the "assaults" on his freedom carried out under various systems that deprive him of autonomy, the right to his own opinion, and to self-determination. So far, it has been impossible to establish societies that would be free from the appropriation of freedom. The desire to build such a society, Ratzinger believes, definitely presents a genuine wish, but, at the same time, a utopia. He says that anarchy is not the right solution; in any case, it has never existed anywhere in any society. He is amazed by the fact that all revolutions aimed at overthrowing a powerful authority in the name of freedom have strangely led to the installation of another strong, often stronger, or even authoritarian, power.

The Christian faith, the belief in one God as God (as the One which no human political power can subordinate) gives man freedom, an inner autonomy from all systems that are intent on depriving him of this freedom. For faith is a profession, but, at the same time, a renunciation of all gods, thus liberating man from them. The Christian faith demythologises the world, political systems and political authority, especially those that strive for absolute power. It demythologises ideologies, "social dogmas," "cosmic divinization," the power of "pure matter" and all other powers which might totally determine man. Faith releases one from "the worship of the power of the mighty," "the confines of pure reason" and those other powers which seem limitless, invincible and overwhelming, for example, the so-called laws of history (Marxism). Faith also liberates man from himself; it sets him free from the "ability to transcend himself towards the open and infinite truth of being"; it gives him the freedom to overstep the boundaries of his own "self." ${ }^{42}$ For Ratzinger, the Christian faith also means that man opens up to the love of God that forgives his personal sins and misconduct (often unprocessed and hence decomposing) - that man faces real forgiveness: "Faith has to do, and must have to do, with forgiving; that it aims at leading man to recognize that he is a being that can only find himself in the reception and transmission of forgiveness, a being that needs forgiveness even in his best and

Ratzinger, Lud i dom Boży, 594; Ratzinger, Introduction, 58-59. 
purest moments." ${ }^{43}$ Ratzinger believes that without forgiveness, life is impossible in the long run. So only the decision of faith paves the way to freedom within.

The Christian faith states clearly that the earthly "powers," however powerful they may seem, are nothing compared to God. This faith gives believers an inner autonomy although their lives are constrained by society, politics, economy, and culture. Believers must not succumb to their influence; they can oppose them and use them for good purposes. Man has dominion over them, resulting from his belief in God. However, for man to have the inner power of demythologisation and freedom, he has to accept the truth as represented by God beforehand. He has to believe in God. Only then will he experience the liberating power of the Truth (cf. John 8:32). Notably, Ratzinger thinks that the well-known question "What is truth?" posed in the conversation between Pilate and Jesus, is not crucial at that moment. Much more important is that a meeting took place between an earthly ruler representing the most powerful empire of the time - and who had the authority to sentence to, or pardon from, death and the One who did not have, and would not have, any earthly authority, yet had the fullness of power. ${ }^{44}$ The Christian faith gives its believers a share in the authority of Jesus, which is not of this world but comes from the Father; it has no intention of appropriating or taking away anyone's freedom, but it is an authority stemming from love and obedience to the Father. It is not an earthly authority, and this illustrates its radicalism, radical otherness, uniqueness, definitiveness, and invincible strength.

\subsection{The Sixth Premise: There Is Someone Who Has a First-Hand Faith (the Church)}

This premise supporting the epistemological seriousness of the Christian faith is related to the Church of Jesus Christ, which, for the Bavarian theologian, is the one and the same history of the same faith (including the faith of Israel), and also a community of the way of the faith. Ratzinger takes the Church to be a "world of faith," built upon the foundation of people who have "transcended" towards the faith ${ }^{45}$ Faith as a personal decision does not need to be treated as one's own absolute "point zero," completely removed from the experience of others. Ratzinger's argument is very simple. A large majority of those joining the community of the Christian faith do so by the power of the faith received second-hand in order to meet God in a personal encounter - a first-hand faith:

It is at first, as it were, a kind of borrowed faith in which one does not yet comprehend the content of what one believes but has confidence in a convincing living embodiment

\footnotetext{
43 Ratzinger, Introduction, 47.

44 Ratzinger, Jesus of Nazareth. Holy Week, 103-113.

45 Ratzinger, Principles, 350-351.
} 
of it and thus opens the way to one's own growth. It is at first a secondhand faith that is, at the same time, an access to faith 'at firsthand', to a personal encounter with the Lord. For all that, we shall always experience faith to some extent at 'second hand', for it is our human portion to need one another even where there is question of ultimate realities. ${ }^{46}$

According to Ratzinger, the Church's faith is obtained "at first hand." The Christian faith is the faith of the Church that is its first subject. In the Church, and only in her - a community of people walking the path of the faith as the only "community of the way" 47 - the necessary process of faith development leading to Tradition takes place. Ratzinger believes that it is not possible to follow the path of the Christian faith or develop it without the assistance of the Church. ${ }^{48}$

For Ratzinger, the Church and her faith are the important realities which make the Christian faith authentic and epistemologically serious. ${ }^{49}$ Subsequently, it becomes clear that the Christian faith is not validated only "on trust," that is, by the subject's act or decision (or by the intensity of the subjective decision to believe). Ratzinger makes the forthright claim that it is only thanks to the Church - this entity that exists "externally" to individuals - only thanks to "a faith shared with the whole Church," that the faith of a concrete person is "epistemologically comprehensible and tenable." ${ }^{50}$ The faith of the Ecclesia, Ratzinger claims, makes validation possible because it is an objective reality, a fact, one composed of the stories of many believers. Basically, it is one story of the same belief in God that began with Abel and Abraham:

The Church is also more than just the pope, bishops, and priests - sacramental missionaries. The persons mentioned here belong to the Church, but the 'community of the way', which we join through our faith, extends much farther - beyond the line of death. The members of the Church include all saints: Abel and Abraham, and all those witnesses of hope mentioned by the Old Testament, such as Virgin Mary the Mother of God, the Apostles, Thomas Beckett, and Thomas Moore, and also Maximilian Kolbe, Edith Stein, and Mother Theresa. The Church community includes all the unknown and unlisted whose 'faith is known only to Him' - people of all times and places whose hearts want to embrace Christ with hope and love - 'the pioneer and perfecter of faith' (Heb 12:2). ${ }^{51}$

One (real and factual) story of the same faith validates it in a concrete way - it validates its truthfulness. A specific subject of faith never starts its belief with itself only. To make this validation ineffective, one would have to - as we can suppose based on

\footnotetext{
46 Ratzinger, Principles, 351.

47 Ratzinger, "Why I Am Still in the Church," sec.: "Why I Stay in the Church."

48 Słupek, Credo, 63-99, 155-184; Słupek, "Benedykta XVI apologia," 217-235.

49 Borto, "Josepha Ratzingera ujęcie wiarygodności," 203-216.

50 Ratzinger, Wiara w Piśmie, II, 830.

51 Ratzinger, Kościót, II, 1138.
} 
Ratzinger's thoughts - "invalidate" both the historical continuity of the same faith in one God, and the nobility, holiness, and heroism of the people of that faith.

Ratzinger is fascinated by the people of faith who have made a "leap" into faith or to whom faith "came" with so much obviousness that they had no other honest option but to embrace it. For him such people, apart from the many biblical figures, are: Augustine, Blaise Pascal, John Henry Newman, Romano Guardini ${ }^{52}$ as well as Bonaventure, Francis of Assisi, Ignatius Loyola, the Dominican Priest Las Casas, Vincent de Paul, Charles de Foucauld, Edith Stein, Maximilian Kolbe, John XXIII, and Mother Theresa. ${ }^{53}$ Ratzinger devoted his doctoral dissertation to Saint Augustine, and his habilitation thesis to Saint Bonaventure; hence, we can venture the statement that, aside from theological problems that he sought in their works, he might have been more interested in examining how exactly they discovered the "obviousness" of the Christian faith - in other words, how they believed, what gave them an insight into their faith, enabling them to give outstanding testimonies of their lives.

\subsection{The Seventh Premise: The Vital Need of People of Faith and Trust}

This premise is represented by the simple question once posed by Ratzinger: "What would happen without the Christian faith and people of faith?" His answer was: "If the Church were no more, if there were no more people in the Church taking the faith seriously, the world would be different. If the faith of Christians faded away, then - without overstating - we could say that 'the heaven would fall' on our world. This would be its ruin, not liberation." ${ }^{54}$

Why did he say that? One explanation can be found in the argument that if there were no people of faith, there would be no people to trust. All of us, believers or non-believers, need someone trustworthy, someone with whom we can share our deepest secrets - who can be entrusted, in a sense, with ourselves. When is someone worthy of our trust? Well, as the Bavarian theologian explains, only when he or she lives by the trust, love and forgiveness that come from without: when we live by faith - the Christian faith. It helps us to stay humble, knowing that we are not omnipotent but limited, that we need Someone Infinite to carry us through our lives. We can help others bear the burden of their lives only when we believe that our own burden is truly borne by the love of Someone else - God, whose love makes him vouch for us, stand in for us, and redeem us. ${ }^{55}$

\footnotetext{
52 Ratzinger, "The Spiritual Basis."

53 Ratzinger, "On the Global Task," sec.: "Why I Stay in the Church."

54 Ratzinger, Kościót, II, 997.

55 Ratzinger, "The Salvation of Man," sec.: "Eternity as the Present."
} 


\section{Conclusions}

The first part of this article gives a general explanation of the Christian faith in Ratzinger's theology. For him, the Christian faith is so original and of great value to Christians - a value that is fundamental to everything - that on this basis alone it is perfectly achievable or even necessary to raise a separate argument for Christianity. The epistemological seriousness and rationality of faith does not only result from (as some atheists think) the limitations of reason, and the decision to believe is not just an act of desperation caused by the psychological mechanism of man's self-defence against plunging into nihilism and despair, which sap all of his vital powers. For Ratzinger, faith is a profoundly rational attitude (although it cannot be taught only by speculations of reason) that can - and it factually desires to - explain and validate itself on the basis of its own self-consciousness and long experience in history.

Ratzinger defends the Christian faith epistemologically. His main premises collected in the second part of this article are as follows: the limitations of reason as not absolute and not omnipotent; faith (although it seems to be totally individual, subjective) always comes from outside a subject (which makes faith epistemologically trustworthy); only faith discloses the truth of our being and the truth (substance) of all things; no one (including science and scientific reason) has definitive proof, and every human being has to have some kind of belief; only faith (in one personal God who exists, speaks and acts) truly gives freedom; there is someone who is capable of being an epistemological guarantee of the Christian faith (the Church who has a first-hand faith); the necessary need of people of faith and trust (only people of faith and trust could be trusted; what would happen to the world without them?).

How should Ratzinger's argument be evaluated? Firstly, the recreated argument is but one of many different ways of argumentation found in his theology. Secondly, what makes this particular (recreated here) argument strong is the quality of its premises: each could be treated as a separate argument (defending Christianity). All those premises are deep-set in reality, logical thinking, and true human experience. Thirdly, Ratzinger's argument stays close to those of (besides St. Augustine and St. Bonaventure) Blaise Pascal, John Henry Newman, Karl Barth, Romano Guardini and Hans Urs von Balthasar. This kind of argumentation is still quite rare in contemporary Christian apologetics and fundamental theology (the fides et ratio argumentation pattern seems to be much more preferred). This is probably due to a fear of being accused of paralogism or of making a logical mistake. At first glance, indeed, this way of argumentation (called sometimes "faith-from-faith" argument) seems to be logically defective. But when patiently recreated and thought over, it is logical and consistent. Ratzinger's position seems to be very consistent: if the goal of fundamental theology (apologetics) is to lead a person to the Christian faith, it is obvious that 
fundamental theology must explain first what that faith is all about. This is the reason why in Ratzinger's theology faith is the point of departure.

Ratzinger is certain that the Christian faith can defend itself epistemologically "from itself" (from its own self-consciousness). Seen from the meta-faith perspective as "a fundamental decision which affects all spheres of our existence," as an act of freedom (from all worldly powers and individual weaknesses) and as an act of choosing metaphysical humility towards reality, faith is epistemologically serious. However, for Ratzinger, at the epistemological root (and seriousness) of the Christian faith lies not the power of individual experience ("The reality of God is greater than all our experience, even our experience of God"56), but some historical content (historical facts) which validates the basic Christian axiom (that Jesus from Nazareth is truly the Christ, the Son of God, the Messiah). Without such historical substance, faith would not have come into being. For the Bavarian theologian, the faith of the Church is an objective reality, a historical fact. It is also a fact that the Church (Christianity) is situated on a long line of history between God and men: one history of the same belief in God that began with Abel and Abraham. It is a fact that this "one history" of one faith is confirmed by the multitude of witnesses (their faith "has written" the Bible; the Bible is a historical fact, too). Among those witnesses were those who have met him alive "on the third day," and this fact founded the Church and her faith (Christianity).

Finally, Ratzinger believes that today "faith must create its own philosophy" as it happened in the era of the Church Fathers. ${ }^{57}$ This is mainly because contemporary philosophies have been built upon different grounds and assumptions than the Christian faith, hence their inability to manifest a Christian perception of reality and the Christian truths of the faith. They have rejected metaphysics and ontology (the truth of our being, the substance of all things) - a view beyond the material and measurable. We can venture the claim that Ratzinger has created precisely this kind of philosophy, a broad Christian theo-ontology as a Christian interpretation (understanding) of reality, being, and existence. He has done so as Joseph Ratzinger (a professor of theology, a bishop and President of the Congregation of the Doctrine of the Faith) and also as Pope Benedict XVI. He has always been consistent: what opens our eyes (absolutely, definitively, always newly, always from outside of our immanence) and leads us to the truth is the Christian faith as the faith of the Church who has a first-hand experience of the living Lord and (in consequence) first-hand faith. This faith deserves our faith.

Translated by Tomasz Pałkowski

56 Ratzinger, Principles, 346.

57 Ratzinger, "The Philosophical Problem." 


\section{Bibliography}

Borto, P., “Josepha Ratzingera ujęcie wiarygodności Kościoła," Teologia fundamentalna w twórczości Josepha Ratzingera (eds. K. Kaucha - J. Mastej) (Lublin: Wydawnictwo KUL 2017) 203-216.

Borto, P., Magisterium Kościoła w sporze z modernizmem o fundamenty wiary. Analiza pogladów A. Loisy'ego, É. Le Roy i G. Tyrrella i ich ocena w świetle dokumentów antymodernistycznych oraz Vaticanum II (Lublin: Wydawnictwo KUL 2020).

Fisichella, R., "Verità, fede e ragione in J. Ratzinger," PATH 6/1 (2007) 27-43.

John Paul II, Encyclical Letter Fides et ratio (Rome: Libreria Editrice Vaticana 1998).

Kałuża, K., "Josepha Ratzingera koncepcja teologii fundamentalnej. Próba rekonstrukcji," Teologia fundamentalna w twórczości Josepha Ratzingera (eds. K. Kaucha - J. Mastej) (Lublin: Wydawnictwo KUL 2017) 47-80.

Lekka-Kowalik, A., "Przymierze na rzecz rozumu i prawdy. Josepha Ratzingera koncepcja filozofii i jej relacji do wiary i teologii," Teologia fundamentalna w twórczości Josepha Ratzingera (eds. K. Kaucha - J. Mastej) (Lublin: Wydawnictwo KUL 2017) 17-45.

Mastej, J., "Paschalna wiarygodność chrześcijaństwa i Kościoła według Josepha Ratzingera/Benedykta XVI," Teologia fundamentalna w twórczości Josepha Ratzingera (eds. K. Kaucha J. Mastej) (Lublin: Wydawnictwo KUL 2017) 135-151.

Mastej, J., Od objawienia do wiary. Personalistyczna koncepcja aktu wiary chrześcijańskiej (Lublin: Redakcja Wydawnictw KUL 2001).

Mastej, J., "Wiara," Leksykon teologii fundamentalnej (eds. M. Rusecki et al.) (Lublin - Kraków: Wydawnictwo M 2002) 1323-1328.

Ratzinger, J., Principles of Catholic Theology. Building Stones for a Fundamental Theology (trans. M.F. McCarthy) (San Francisco, CA: Ignatius 1987).

Ratzinger, J., "Conversion, Faith and Thought," J. Ratzinger, The Nature and Mission of Theolo$g y$ (trans. A. Walker) (San Francisco, CA: Ignatius 1995) [EPUB].

Ratzinger, J., "The Spiritual Basis and Ecclesial Identity of Theology," J. Ratzinger, The Nature and Mission of Theology (trans. A. Walker) (San Francisco, CA: Ignatius 1995) [EPUB].

Ratzinger, J., "God and Reason," J. Ratzinger, God and the World. Believing and Living in Our Time (trans. H. Taylor) (San Francisco, CA: Ignatius 2002) [EPUB].

Ratzinger, J., Introduction to Christianity, 2 ed. (trans. J.R. Foster) (San Francisco, CA: Ignatius 2004).

Ratzinger, J., "The Church on the Threshold of the Third Millennium," Pilgrim Fellowship of Faith. The Church as Communion (trans. H. Taylor) (San Francisco, CA: Ignatius 2005) 284-298 [EPUB].

Ratzinger, J., “The Nature of Tradition," J. Ratzinger, God's Word. Scripture - Tradition - Office (trans. H. Taylor) (San Francisco, CA: Ignatius 2008) [EPUB].

Ratzinger, J., “On Hope," Communio 35/2 (2008) 301-315.

Ratzinger, J., Künder des Wortes und Diener eurer Freude (Gesammelte Schriften 12; Freiburg im Breisgau - Basel - Wien: Herder 2010).

Ratzinger, J., Dogma and Preaching. Applying Christian Doctrine to Daily Life (trans. M.J. Miller-M.J. O’Connell) (San Francisco, CA: Ignatius 2011).

Ratzinger, J., Jesus of Nazareth. Holy Week, From the Entrance into Jerusalem to the Resurrection (trans. P.J. Whitmore) (San Francisco, CA: Ignatius 2011). 


\section{KRZYSZTOF KAUCHA}

Ratzinger, J., Głosiciele Słowa i słudzy Waszej radości. Teologia i duchowość sakramentu święceń (eds. K. Góźdź - M. Górecka) (Joseph Ratzinger Opera Omnia 12; Lublin: Wydawnictwo KUL 2012).

Ratzinger, J., "On the Global Task of the Christian Faith," J. Ratzinger, Fundamental Speeches from Five Decades (San Francisco, CA: Ignatius 2012) [EPUB].

Ratzinger, J., "The Question about Jesus' Origin as a Question about Being and Mission," J. Ratzinger, Jesus of Nazareth. The Infancy Narratives (trans. P.J. Whitmore) (New York: Image 2012) [e-Book].

Ratzinger, J., “The Salvation of Man-This-Worldly and Christian,” J. Ratzinger, Fundamental Speeches from Five Decades (San Francisco, CA: Ignatius 2012) [EPUB].

Ratzinger, J., "Why I Am Still in the Church," J. Ratzinger, Fundamental Speeches from Five Decades (San Francisco, CA: Ignatius 2012) [EPUB].

Ratzinger, J., Kościót - znak wśród narodów. Pisma eklezjologiczne i ekumeniczne (Joseph Ratzinger Opera Omnia 8/1-2; Lublin: Wydawnictwo KUL 2013) I-II.

Ratzinger, J., "Eucharist," J. Ratzinger, Theology of the Liturgy (Collected Works 11; San Francisco, CA: Ignatius 2014) [EPUB].

Ratzinger, J., Lud i dom Boży w nauce św. Augustyna o Kościele. Rozprawa doktorska oraz inne opracowania nauki Augustyna i teologii ojców Kościoła (Joseph Ratzinger Opera Omnia 1; Lublin: Wydawnictwo KUL 2014).

Ratzinger, J., "The Philosophical Problem of Transubstantiation," J. Ratzinger, Theology of the Liturgy (Collected Works 11; San Francisco, CA: Ignatius 2014) [EPUB].

Ratzinger, J., Rozumienie objawienia i teologia historii według Bonawentury. Rozprawa habilitacyjna i studia nad Bonawentura (Joseph Ratzinger Opera Omnia 2; Lublin: Wydawnictwo KUL 2014).

Ratzinger, J., Jezus z Nazaretu. Studia o chrystologii (Joseph Ratzinger Opera Omnia 6/2; Lublin: Wydawnictwo KUL 2015) II.

Ratzinger, J., W rozmowie z czasem (Joseph Ratzinger Opera Omnia 13/3; Lublin: Wydawnictwo KUL 2018) III.

Ratzinger, J., Wiara w Piśmie i Tradycji. Teologiczna nauka o zasadach (Joseph Ratzinger Opera Omnia 9/1-2; Lublin: Wydawnictwo KUL 2018) I-II.

Rusecki, M. - Mastej, J. - Kaucha, K., Metodologia teologii fundamentalnej(Lublin: TN KUL 2019).

Słupek, R., "Benedykta XVI apologia eklezjalnego wymiaru wiary chrześcijańskiej," Teologia fundamentalna w twórczości Josepha Ratzingera (eds. K. Kaucha - J. Mastej) (Lublin: Wydawnictwo KUL 2017) 217-235.

Słupek, R., Credo et credimus Ecclesiam. Eklezjalność wiary chrześcijańskiej w nauczaniu papieskim przełomu XX i XXI wieku (Jan Paweł II, Benedykt XVI, Franciszek) (Kraków: Salwator 2017). 